\title{
How to Prevent Burnout in Medical Residents: Literature Review
}

\author{
Yu-Chung Juan ${ }^{1,2}$ and Chi-Wen Juan ${ }^{3,4 *}$ \\ ${ }^{1}$ Department of medicine, Taichung Veterans General Hospital, Taiwan \\ ${ }^{2}$ Research Institute of Biotechnology, Hungkuang University, Taiwan \\ ${ }^{3}$ Department of Emergency Medicine, Kuang-Tien General Hospital, Taiwan \\ ${ }^{4}$ Department of Nursing, Hungkuang University, Taiwan
}

*Corresponding author: Chi-Wen Juan, Department of Emergency Medicine, Kuang-Tien General Hospital Shatian Road Shalu District, Taiwan.

To Cite This Article: Chi-Wen Juan. How to Prevent Burnout in Medical Residents: Literature Review. Am J Biomed Sci \& Res. 2019 - 5(2). AJBSR. MS.ID.000898. DOI: 10.34297/AJBSR.2019.05.000898.

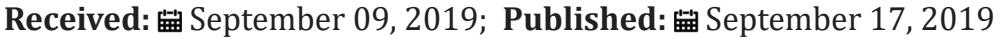

\begin{abstract}
Background: Healthy settings involve a holistic and multidisciplinary method that integrates actions towards risk factors. In hospital settings, a high level of stress can lead to depression, anxiety, decreased job satisfaction and lower loyalty to the organization.

Objective: This study was to perform a systematic literature review and meta-analysis of the prevalence of burnout among medical residents to develop strategies to support residents' personal and professional development.

Methods: The Medline database was searched with burnout and resident search words. Inclusion criteria of articles for review were published in an English-language peer-reviewed journal from January 2010 to October 2018.Total 12 eligible studies were included in literature review.

Results: We identified 12 studies including 9796 participants, conducted across the world and covering different specialties which include Oncology, EM, Otolaryngologist, Psychiatry, General surgery, Pediatrics, Neurosurgery and Radiology. All the 12 studies included 11 articles on descriptive cross-sectional studies and 1 article on analysis of variance, longitudinal study. Review results mainly pointed out the significance high prevalence and the need for systematic measures for prevention medical residents' burnout.
\end{abstract}

Conclusion: These studies revealed high level of burnout among medical residents, whose stresses were mainly from working situation, emotional pressure and demands from patients. Action plan for resident burnout syndrome prevention is to develop a better training program and enhance medical resident well-being.

Keywords: Burnout; Medical residents; Stress; Well-being

\section{Introduction}

Burnout is a work-related syndrome that is characterized by high levels of emotional exhaustion and depersonalization, and a reduction in the level of personal accomplishment, which are all driven by workplace stressors [1]. The term burnout was introduced by psychologist Herbert Freudenberger in 1974 in an article entitled "Staff Burnout," in which he discusses job dissatisfaction caused by professional stress [2]. This syndrome has severe adverse consequences including substance abuse, disruptive behavior, lack of energy, low job satisfaction, absenteeism, worthless, impatience, divorce, depression, suicidal thinking, and even suicide [3]. The assessment of burnout syndrome among physicians is performed in a standardized manner using the Maslach Burnout Inventory (MBI), a validated instrument consisting of 22 items that measure scores for 3 dimensions associated with burnout, which is characterized by high scores for emotional exhaustion and depersonalization, and/or low scores of personal accomplishment [4]. Resident burnout is a major concern because it has serious consequences on patient outcomes and on the personal lives of medical residents. Therefore, the objective of this study was to perform a systematic literature review and meta-analysis of the prevalence of burnout among medical residents to develop strategies to support residents' personal and professional development.

\section{Materials and Methods}

The Medline database was searched with burnout and resident search words. Inclusion criteria of articles for review were published in an English-language peer-reviewed journal from January 2010 to October 2018, study was conducted no earlier than 2010 
and search words appear in the title and/or abstract. Studies were excluded if they did not focus primarily on burnout of residents. The entire systematic review process was conducted by the author. The initial search identified 185 articles. Articles were further screened using the above inclusion criteria, and 39 were selected. Twenty-seven of these were excluded due to lack of focus on resident burnout. This resulted in a total of 12 articles for analysis in this review (Figure 1)

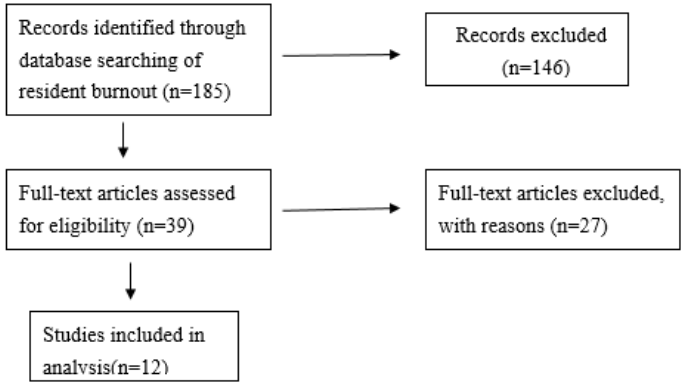

Figure 1: Flow diagram.

\section{Results}

Search results are shown in Figure 1. Systematic review included 11 articles on descriptive cross-sectional studies and 1 article on analysis of variance, longitudinal study. This literature review was focused on the prevalence of burnout comparison among different medical specialties residents in different countries to develop strategies to support residents' personal and professional development. Studies surveyed in analysis are shown in Table 1.

\section{Discussion}

During the medical residency training years, compared to other periods of professional development, medical residents must adjust to tougher workloads, higher professional self-expectations, and increased demands from patients [5]. Burnout among medical residents is highly prevalent. High educational demands, long working hours, sleep deprivation, on- call alert, lack of autonomy, a high level of work-home interference, a lack of reciprocity in professional relationships and uncertainty about the future are common explanations. Many studies have shown medical residents from various specialties, internationally, experienced moderate burnout. The prevalence of medical residents who met the criteria of burnout on MBI ranged from $17 \%$ to $76 \%$. If medical residents are made aware of potentially detrimenta1 personal characteristics, and adjust their behavior and coping styles accordingly, they may better meet the various challenges in their medical career. Failing to cope with the stress will have negative impact on their work performance and the quality of patient care. This review covered the incidence of burnout during resident period and based on these results we are able to offer possible solutions for health care institutions.

\begin{tabular}{|c|c|c|c|c|c|}
\hline $\begin{array}{l}\text { Authors, } \\
\text { year }\end{array}$ & $\begin{array}{c}\text { Type of study ques- } \\
\text { tionnaire }\end{array}$ & $\begin{array}{l}\text { Popula- } \\
\text { tion }\end{array}$ & Country & Aim & Conclusion/Implication \\
\hline $\begin{array}{l}\text { Prins et al. } \\
(2010)[5]\end{array}$ & $\begin{array}{l}\text { Descriptive, cross-sec- } \\
\text { tional study ,Dutch } \\
\text { version of the MBI Hu- } \\
\text { man Services Survey }\end{array}$ & $\begin{array}{l}\mathrm{N}=5140, \\
\text { response } \\
\text { rate } 41 \%\end{array}$ & $\begin{array}{l}\text { Dutch medical } \\
\text { residents, Neth- } \\
\text { erlands }\end{array}$ & $\begin{array}{l}\text { To gather insight into } \\
\text { the well-being of Dutch } \\
\text { medical residents. }\end{array}$ & $\begin{array}{l}21 \% \text { fulfilled the criteria for moderate to severe } \\
\text { Burnout. General surgery represented the specialty } \\
\text { with the lowest number of residents suffering from } \\
\text { burnout, followed by obstetrics and gynecology } \\
\text { and any supportive specialty. }\end{array}$ \\
\hline $\begin{array}{l}\text { Blanchard } \\
\text { et al. } \\
\text { (2010) [6] }\end{array}$ & $\begin{array}{l}\text { Descriptive, cross-sec- } \\
\text { tional study , MBI }\end{array}$ & $\begin{array}{l}\mathrm{N}=340 \\
\text { response } \\
\text { rate } 60 \%\end{array}$ & $\begin{array}{l}\text { Oncology resi- } \\
\text { dents,b France }\end{array}$ & $\begin{array}{l}\text { To assess the prevalence } \\
\text { and causes of burnout } \\
\text { among oncology resi- } \\
\text { dents. }\end{array}$ & $\begin{array}{c}\text { The burnout level is high (44\%) amongst oncology } \\
\text { residents. It probably discourages vocations for } \\
\text { oncology. }\end{array}$ \\
\hline $\begin{array}{l}\text { Takayesu et } \\
\text { al. (2014) } \\
\text { [7] }\end{array}$ & $\begin{array}{l}\text { Descriptive, cross-sec- } \\
\text { tional study , MBI }\end{array}$ & $\begin{array}{l}\mathrm{N}=289 \\
\text { response } \\
\text { rate } 75 \%\end{array}$ & $\begin{array}{l}\text { Emergency } \\
\text { medicine (EM) } \\
\text { residents, USA }\end{array}$ & $\begin{array}{l}\text { To assess the preva- } \\
\text { lence of burnout among } \\
\text { EM residents and the } \\
\text { individual-level factors } \\
\text { associated with burnout. }\end{array}$ & $\begin{array}{l}\text { Burnout is highly prevalent ( } 65 \% \text { ) in EM residents. } \\
\text { Interventions should be targeted at 1) improving } \\
\text { resident autonomy 2) supervision and instruction } \\
\text { on medical decision-making and 3) social supports } \\
\text { to reduce work-home conflicts during training. }\end{array}$ \\
\hline $\begin{array}{l}\text { Aldrees et } \\
\text { al. }(2015) \\
\quad[8]\end{array}$ & $\begin{array}{l}\text { Descriptive, cross-sec- } \\
\text { tional study , MBI }\end{array}$ & $\begin{array}{l}\mathrm{N}=123 \\
\text { response } \\
\text { rate } 69 \%\end{array}$ & $\begin{array}{l}\text { Otolaryngology } \\
\text { residents, Saudi } \\
\text { Arabia }\end{array}$ & $\begin{array}{l}\text { Determine the preva- } \\
\text { lence of, and associated } \\
\text { risk factors for, burnout } \\
\text { among otolaryngologist } \\
\text { residents in Saudi Arabia. }\end{array}$ & $\begin{array}{l}\text { Burnout prevalence was found to be high(33\%) } \\
\text { among otolaryngologist residents in Saudi Arabia. } \\
\text { The associated variables examined in this study } \\
\text { should be addressed to decrease this level of } \\
\text { burnout and provide residents with a less stressful } \\
\text { work environment. }\end{array}$ \\
\hline $\begin{array}{l}\text { Miyoshi et } \\
\text { al. (2016) } \\
\quad[9]\end{array}$ & $\begin{array}{l}\text { Analysis of variance, } \\
\text { longitudinal study, TCI, } \\
\text { MBI-GS, SDS }\end{array}$ & $\begin{array}{l}\mathrm{N}=89 \\
\text { response } \\
\text { rate } \\
95.5 \%\end{array}$ & $\begin{array}{l}\text { University of } \\
\text { Miyazaki Hos- } \\
\text { pital residents, } \\
\text { Japan }\end{array}$ & $\begin{array}{l}\text { High risk of burnout in } \\
\text { healthcare workers has } \\
\text { long been recognized. } \\
\text { However, there are no } \\
\text { methods to predict vul- } \\
\text { nerability to burnout. }\end{array}$ & $\begin{array}{l}23.5 \% \text { of participants were newly identified with } \\
\text { burnout using the MBI-GS and } 15.3 \% \text { of partici- } \\
\text { pants were newly diagnosed with depressive state } \\
\text { using the SDS. Our results suggest that the TCI can } \\
\text { predict not only the risk for future depressive state } \\
\text { but also the risk for future burnout. }\end{array}$ \\
\hline $\begin{array}{l}\text { Kealy et al. } \\
\text { (2016) [10] }\end{array}$ & $\begin{array}{l}\text { Descriptive, cross-sec- } \\
\quad \text { tional study, MBI } \\
\text { emotional exhaustion } \\
\text { scale. ikert-scale items }\end{array}$ & $\begin{array}{l}\mathrm{N}=400 \\
\text { response } \\
\text { rate } 48 \%\end{array}$ & $\begin{array}{l}\text { Psychiatry resi- } \\
\text { dents Canadian, }\end{array}$ & $\begin{array}{l}\text { While burnout is known } \\
\text { to affect residents, no } \\
\text { studies have examined } \\
\text { the prevalence or impact } \\
\text { of burnout among Cana- } \\
\text { dian psychiatry residents. }\end{array}$ & $\begin{array}{l}\text { The incidence of burnout symptoms among } \\
\text { one-fifth( } 21 \%) \text { of Canadian psychiatry residents } \\
\text { warrants the attention of psychiatric educators, } \\
\text { program directors, and residents themselves. }\end{array}$ \\
\hline
\end{tabular}




\begin{tabular}{|c|c|c|c|c|c|}
\hline $\begin{array}{l}\text { Elmore et } \\
\text { al. (2016) } \\
\quad[11]\end{array}$ & $\begin{array}{l}\text { Descriptive, cross-sec- } \\
\text { tional study, MBI }\end{array}$ & $\begin{array}{l}\mathrm{N}=753 \\
\text { response } \\
\text { rate } \\
88.3 \%\end{array}$ & $\begin{array}{l}\text { General surgery } \\
\text { residents, USA }\end{array}$ & $\begin{array}{l}\text { To present findings from } \\
\text { a national survey to de- } \\
\text { termine the prevalence of } \\
\text { burnout among general } \\
\text { surgical trainees and to } \\
\text { identify sociodemograph- } \\
\text { ic and program charac- } \\
\text { teristics associated with } \\
\text { burnout. }\end{array}$ & $\begin{array}{l}\text { The high rates }(60 \%) \text { of burnout among general } \\
\text { surgery residents are concerning given the po- } \\
\text { tential impact of burnout on the quality of patient } \\
\text { care. Efforts to identify at-risk populations and to } \\
\text { design targeted interventions to mitigate burnout } \\
\text { in surgcal trainees are warranted. }\end{array}$ \\
\hline $\begin{array}{c}\text { Baer et } \\
\text { al. }(2017) \\
{[12]}\end{array}$ & $\begin{array}{l}\text { Descriptive, cross-sec- } \\
\text { tional study, MBI }\end{array}$ & $\begin{array}{l}\mathrm{N}=258 \\
\text { response } \\
\text { rate } 53 \%\end{array}$ & $\begin{array}{l}\text { Pediatric resi- } \\
\text { dents, USA }\end{array}$ & $\begin{array}{l}\text { To determine the prev- } \\
\text { alence of burnout, and } \\
\text { examine the association } \\
\text { between burnout and } \\
\text { self-reported patient care } \\
\text { attitudes and behaviors } \\
\text { among pediatric resi- } \\
\text { dents. }\end{array}$ & $\begin{array}{l}\text { Burnout is highly prevalent(39\%) among pediatric } \\
\text { residents and is associated with self-reported nega- } \\
\text { tive patient care attitudes and behaviors. Residency } \\
\text { programs should develop interventions address- } \\
\text { ing burnout and its potential negative impact on } \\
\text { patient care. }\end{array}$ \\
\hline $\begin{array}{c}\text { Shakir et } \\
\text { al. (2017) } \\
\text { [13] }\end{array}$ & $\begin{array}{l}\text { Descriptive, cross-sec- } \\
\text { tional study, aMBI }\end{array}$ & $\begin{array}{l}\mathrm{N}=1200 \\
\text { response } \\
\text { rate } \\
21.3 \%\end{array}$ & $\begin{array}{l}\text { Neurosurgery } \\
\text { residents, USA }\end{array}$ & $\begin{array}{l}\text { To determine and } \\
\text { compare the prevalence } \\
\text { of burnout among US } \\
\text { neurosurgery residents } \\
\text { with published rates for } \\
\text { residents/fellows and } \\
\text { practicing physicians } \\
\text { from other specialties. }\end{array}$ & $\begin{array}{l}\text { Neurosurgery residents have a significantly } \\
\text { lower prevalence (36.5\%)of burnout than other } \\
\text { residents/fellows and practicing physicians. The } \\
\text { underlying causes for these findings were not } \\
\text { assessed and are likely multifactorial. }\end{array}$ \\
\hline $\begin{array}{l}\text { Guenette et } \\
\text { al. (2017) } \\
{[14]}\end{array}$ & $\begin{array}{l}\text { Descriptive, multiple } \\
\text { linear regression } \\
\text { cross-sectional study, } \\
\text { MBI-HSS }\end{array}$ & $\begin{array}{l}\mathrm{N}=472 \\
\text { response } \\
\text { rate } \\
19.9 \%\end{array}$ & $\begin{array}{c}\text { Radiology } \\
\text { Residents, New } \\
\text { England }\end{array}$ & $\begin{array}{l}\text { To establish burnout } \\
\text { prevalence, associated } \\
\text { demographic and pro- } \\
\text { gram-related factors, and } \\
\text { degree of burnout in New } \\
\text { England radiology resi- } \\
\text { dents relative to residents } \\
\text { in other specialties. }\end{array}$ & $\begin{array}{l}\text { A high degree of burnout, increasing over the post- } \\
\text { graduate years, was present in more than one-third } \\
\text { of responding radiology residents but was present } \\
\text { in a smaller percentage relative to residents across } \\
\text { other specialties. }\end{array}$ \\
\hline $\begin{array}{l}\text { Vendeloo et } \\
\text { al. (2018) } \\
\text { [15] }\end{array}$ & $\begin{array}{l}\text { Descriptive, cross-sec- } \\
\text { tional study, Dutch } \\
\text { version of the MBI }\end{array}$ & $\begin{array}{l}\mathrm{N}=682 \\
\text { response } \\
\text { rate } \\
34.6 \%\end{array}$ & $\begin{array}{l}\text { residents in a } \\
\text { large univer- } \\
\text { sity hospital } \\
\quad \text {,Belgium }\end{array}$ & $\begin{array}{l}\text { To evaluate the associ- } \\
\text { ation between burnout } \\
\text { and the learning envi- } \\
\text { ronment in a cohort of } \\
\text { Belgian residents. }\end{array}$ & $\begin{array}{l}\text { Resident burnout is highly prevalent(41.5\%) in } \\
\text { our cohort of Belgian residents. Our results suggest } \\
\text { that the learning environment plays an import- } \\
\text { ant role in reducing the risk of burnout among } \\
\text { residents. }\end{array}$ \\
\hline $\begin{array}{l}\text { Jamjoom et } \\
\text { al. (2018) } \\
{[16]}\end{array}$ & $\begin{array}{l}\text { Descriptive, cross-sec- } \\
\text { tional study, aMBI }\end{array}$ & $\begin{array}{l}\mathrm{N}=50 \\
\text { response } \\
\text { rate } \\
91.4 \%\end{array}$ & $\begin{array}{l}\text { Pediatric res- } \\
\text { idents at King } \\
\text { Abdulazaiz Uni- } \\
\text { versity Hospital } \\
\text { in Jeddah, Saudi } \\
\quad \text { Arabia. }\end{array}$ & $\begin{array}{l}\text { To study burnout among } \\
\text { pediatric residents at } \\
\text { King Abdulazaiz Univer- } \\
\text { sity Hospital in Jeddah, } \\
\text { Saudi Arabia. }\end{array}$ & $\begin{array}{l}\text { More than } 70 \% \text { of residents experiencing severe } \\
\text { burnout. Moreover, pediatric residents in our insti- } \\
\text { tute experienced higher levels of depersonalization } \\
\text { than their peers nationally and internationally. }\end{array}$ \\
\hline
\end{tabular}

Burnout refers to a state of fatigue and emotional exhaustion which may cause poor adaptation inducing detachment that develop in response to stress at work. Burnout syndrome is a significant problem in the healthcare system, especially in residents because the pressure of work during residency training remains very high, especially as residents are expected to be proficient clinicians, educator, and administrators at the end of residency-training period. The impact of burnout symptoms on the work capacity and reduction of healthcare quality is important which may directly relate to patient's safety. Therefore, there is the need for designing action plans for burnout prevention and creating a healthy environment in hospitals. Residents are frequently exposed to highly stressful and emotional situations at work, such as high patient workload, unfriendly work environment, lack of recreational services in hospital. Many postgraduate educational programs do not provide enough knowledge about burnout. Due to this reason, it is very important for healthcare institutions to promote programs for prevention and treatment of burnout. Literature review and analysis of 12 studies provided a large number of important and relevant scientific evidence.

We identified 12 studies including 9796 participants, conducted across the world and covering different specialties which include Oncology, EM, Otolaryngologist, Psychiatry, General surgery, Pediatrics, Neurosurgery and Radiology. All the 12 studies included 11 articles on descriptive cross-sectional studies and 1 article on analysis of variance, longitudinal study. Review results mainly pointed out the significance high prevalence and the need for systematic measures for prevention. Our review findings suggest that many negative express from residents can be connected with following reasons. Blanchard et al. [6] indicate that the high level of burnout probably discourages vocations for Oncology [7-8]. The lack of manpower will cause a vicious cycle and aggravate the burnout syndrome. Miyoshi et al. [9] found that participants with burnout have a higher risk become depressive state, which was measured by 
SDS [10-12]. Simultaneously, Baer et al. [12] also report that there is association between the proportion of burnout and self-reported negative patient care attitudes and behaviors [13]. Among those specialty included in these 12 studies, the EM residents seems to be the highest burnout prevalence. Takayesu et al. [7] suggest that intervention should be targeted at

a) Improving resident autonomy

b) Supervision and instruction on medical decision-making and

c) Social supports to reduce work-home conflicts during training [14].

However, work environment is also an important issue. Aldress et al. [8] and Vendeloo et al. [15] both accentuate the learning environment plays an important role in reducing the burnout risk among residents [16-19]. Therefore, aim for decrease level of burnout and provide residents with a less stressful work environment should be a priority. However, factors affecting medical residents prone to burnout need multi-dimensional evaluation in order to reduce the devastating consequences of burnout. In an effort to address widespread burnout and unwellness, our goal is to develop a better training program and enhance medical resident well-being. The major factors associated with medical resident well-being are autonomy, building of competence, strong social relatedness, and sleep time away from work. Perseverance is predictive of well-being, and greater well-being is associated with increased medical resident empathy [20]. For enhancing medical residents well-being, in addition to organizational efforts to reduce work stress, we should need to identify the sources of stresses which the medical residents perceived, to understand the levels of stress outcome as feelings of burnout, to explore the influencing factors, including personal characteristics to medical resident burnout in order to identify residents at risk of burnout early and to provide timely management [21].

\section{Conclusion}

These studies revealed high level of burnout among medical residents, whose stresses were mainly from working situation, emotional pressure and demands from patients. The low burnout residents showed more positive characteristics and active coping styles. Therefore, the lower of burnout syndrome, the better residents can meet the various challenge. Speaking to Taiwan, government dedicate to making residents apply to the Labor Standard laws to protect our residents from burnout syndrome on 2019.We can foresee the future of adequate balance of workload and patients safety in Taiwan.

\section{References}

1. Mc Cray LW, Cronholm PF, Bogner HR (2008) Resident physician burnout: is there hope? Fam Med 40(9): 626-632.
2. Freudenberger HJ, Staff burnout (1974) J Soc Issues. 30(1): 159-165.

3. Ribeiro RVE, Martuscelli OJD, Vieira AC, Vieira CF (2018) Prevalence of Burnout among Plastic Surgeons and Residents in Plastic Surgery: A Systematic Literature Review and Meta-analysis. Plast Reconstr Surg Glob Open 6(8): e1854.

4. Maslach C, Jackson S, Leiter M (1996) Maslach Burnout Inventory. Palo Alto, Calif.: Consulting Psychologists Press.

5. Prins JT, Hoekstra-Weebers JE, Gazendam Donofrio SM, Dillingh GS, Bakker AB, et al. (2010) Burnout and engagement among resident doctors in the Netherlands: a national study. Med Educ 44(3): 236-247.

6. Blanchard P, Truchot D, Albiger-Sauvin L (2010) Prevalence and causes of burnout amongst oncology residents: A comprehensive nationwide cross-sectional study. Eur J Cancer 46(15): 2708-2715.

7. Kimo Takayesu, J Ramoska, EA Clark, TR (2014) Factors associated with burnout during emergency medicine residency. Acad Emerg Med 21(9): 1031-1035.

8. Aldrees T, Badri M, Islam T, Alqahtani K (2015) Burnout among otolaryngology residents in Saudi Arabia: a multicenter study. J Surg Educ 72(5): 844-848.

9. Miyoshi R, Matsuo H, Takeda R, Komatsu H, Abe H, et al. (2016) Burnout in Japanese residents and its associations with temperament and character. Asian Journal of Psychiatry 24: 5-9.

10. Kealy D, Halli P, Ogrodniczuk JS, Hadjipavlou G (2016) Burnout among canadian psychiatry residents: a national survey. Can J Psychiatry 61(11): 732-736.

11. Elmore C, Jeffe Donna B, Linda Jin, Awad Michael M, Turnbull Isaiah R, et al. (2016) National Survey of Burnout among US General Surgery Residents Leisha. J Am Coll Surg 223: 440-451.

12. Baer TE, Feraco AM, Tuysuzoglu Sagalowsky S (2017) Pediatric Resident Burnout and Attitudes Toward Patients. Pediatrics 139(3): e20162163.

13. Shakir HJ, McPheeters MJ, Shallwani H, Pittari JE, Reynolds RM, et al. (2018) The Prevalence of Burnout Among US Neurosurgery Residents. Neurosurgery 83(3): 582-590.

14. Guenette JP, Smith SE (2017) Burnout: Prevalence and Associated Factors Among Radiology Residents in New England With Comparison Against United States Resident Physicians in Other Specialties. AJR Am J RoentgenolJul 209(1): 136-141.

15. Van Vendeloo SN, Godderis L, Brand PLP, Verheyen KCPM, Rowell SA, et al. (2018) Resident burnout: evaluating the role of the learning environment. BMC Med Educ 18(1): 54.

16. Jamjoom RS, Park YS (2018) Assessment of pediatric residents burnout in a tertiary academic centre. Saudi Med J 39(3):296-300.

17. Lue BH, Kao MY, Chen HJ, Wang CW (2011) The association of resident burnout with personal characteristics and coping styles. J Med Education 15(1): 21-30.

18. Dyrbye L, Shanafelt T (2016) A narrative review on burnout experienced by medical students and residents. Med Educ 50:132-149.

19. Krug MF, Golob AL, Wander PL, Wipf JE (2017) Changes in resident well-being at one institution across a decade of progressive work hours limitations. Acad Med 92(10):1480-1484.

20. Lue BH, Chen HJ, Wang CW, Cheng Y, Chen MC, et al. (2010) Stress, personal characteristics and burnout among first postgraduate year residents: a nationwide study in Taiwan. Med Teach 32(5): 400-407.

21. Raj KS (2016) Well-Being in Residency: A Systematic Review. J Grad Med Educ 8(5): 674-684. 